\title{
Obstacles to the Development of Critical Thinking Dispositions Among Student Teachers at Morgenster Teachers' College, Zimbabwe
}

\author{
Doi:10.5901/mjss.2013.v4n6p671
}

\author{
Davison Zireva \\ Moeketsi Letseka \\ Morgenster Teachers College \\ University of South Africa \\ E-mail: letsem@unisa.ac.za
}

\begin{abstract}
This article explores obstacles to the development of critical thinking dispositions at Morgenster Teachers' College (MTC) in Zimbabwe. MTC is a private college of the Reformed Church in Zimbabwe (RCZ) with an enduring history of evangelism. An estimated 50 per cent of the students are admitted on the strength of their exemplary participation in their respective parishes. About 80 per cent of lecturers are church members with reputable track records in church ministry. They are champions of conformity to religious doctrines and their pedagogical approaches are 'monologic' - one dimensional and 'insular'. Monologic pedagogy is analogous to what Brazilian philosopher of education Paulo Freire labelled the 'banking concept of education' in his highly acclaimed book, Pedagogy of the Oppressed. In this article we question the educational viability of monologic pedagogy and argue that it is potentially indoctrinatory. We suggest a shift in the college's pedagogy to a Socratic selfexamination and a Freirean critical dialogue, complemented by students' own research and opportunities for critical reflection on their work in interactive research seminars
\end{abstract}

Keywords: Morgenster Teachers' College, banking education, evangelism, dogmatic orientation, indoctrination, critical thinking dispositions

\section{Introduction}

In this article we explore obstacles to the development of critical thinking dispositions at Morgenster Teachers' College (MTC) in Zimbabwe. The notion of 'critical thinking' has been widely delineated (Title 2011; Egege and Utieleh 2004; Schlosser, Visser and Visser 2003; Van den Berg 2000; Beyer, 1988; Ennis 1996, 1993, 1989). Daniel and Auriac (2011, 418) remind us that despite the lack of consensus, the definitions of five American philosophers have served as references: Robert Ennis, Matthew Lipman, Richard Paul, John McPeck and Harvey Siegel". We briefly sketch some of the conceptions of "critical thinking' and debate 'what critical thinking is?", and 'why is it so important to teaching and learning?'. Perhaps we should start by providing a brief background to MTC. MTC is a private teachers' college of the Reformed Church in Zimbabwe (RCZ) in Masvingo, Zimbabwe. It has an enduring history of evangelism. In fact as a requirement for admission prospective students are expected to be model evangelists. An estimated 50 per cent of MTC students are admitted on the strength of their exemplary participation in their respective RCZ parishes. Equally about 80 per cent of the lecturers are church members with reputation in church ministry. They are stern preachers of conformity to church doctrines and employ monologic pedagogy in their lectures.

But as Gravett $(2001,38)$ warns, monologic pedagogy treats 'knowledge' as fixed bodies of facts that are to be transferred to the students, who are 'external' to such 'knowledge'. According to this logic the students are tabula rasa, a Latin phrase for 'clean slates', 'empty vessels', or 'receptacles' that have to be filled with the fixed bodies of facts, which are presumed to constitute 'worthwhile knowledge'. We argue that monologic pedagogy is analogous to what Brazilian philosopher of education Paulo Freire labelled 'the banking concept of education' in his acclaimed book Pedagogy of the Oppressed. Freire $(1972,53)$ argued that "in the banking concept of education, knowledge is a gift bestowed by those who consider themselves knowledgeable upon those whom they consider to know nothing. Projecting an absolute ignorance onto others, a characteristic of the ideology of oppression, negates education and knowledge as processes of inquiry". Our view is that the so-called education where the flow of information is one-dimensional cannot, logically speaking, be called education. Instead it is indoctrination masquerading as education. 
Since the 1960s philosophers of education have been debating the concept of 'indoctrination' (Garrison 1986; Macmillan 1983; Snook 1972a, 1972b; 1970). The debates considered whether indoctrination is necessarily a bad thing or might sometimes be ethically or educationally justifiable (Snook 1972b, 3). They also considered the paradox of indoctrination. As Macmillan $(1983,370)$ argues, "in a modern democratic society, the desired goal of education is that each student develops a set of beliefs that are rationally grounded and open to change when challenged by better-grounded beliefs. In order to develop such students, however, it would seem that they must acquire a belief in rational methods of knowing which must itself be beyond challenge, i.e., held in a manner inconsistent with its own content. Thus, students must be indoctrinated in order not to be indoctrinated: a pedagogical dilemma or paradox". But Garrison $(1986,264)$ notes that "this paradox is neither vicious nor inescapable. It is not even a paradox for those unopposed to indoctrination or unaware of such an idea. The paradox isn't even especially logical; involving as it does normative considerations. It certainly does however, challenge the possibility of a fully rational education".

New Zealand philosopher of education Ivan Snook was hopeful in his book, Indoctrination and Education that "once indoctrination is clearly understood, it will be obvious that it is reprehensible, although there will be disagreement as to why it is" (Snook 1972a, 3). While Snook $(1970,56)$ presumed that "indoctrination is a pejorative term", he cautioned that "far from it being the case that 'teaching' excludes 'indoctrination', there is a necessary or conceptual relationship between them" (Snook 1972a, 47). Our view is that monologic pedagogy is counterproductive to education's mandate of creating citizens ${ }^{1}$ that are functional and responsible. Given that monologic pedagogy predominates at MTC, it is our view that the college's pedagogical principles and practices are not amenable to the development of critical thinking dispositions. To resolve this problem we propose a shift to the Freirean dialogical engagement that is anchored in the Socratic self-examination and fearless speech or parrhesia.

This article is structured around four sections. First we describe the methodology for collecting the data and highlight the University of South Africa (UNISA)'s policy on the code of research ethics, which guided the study from which this article draws. Second, we sketch emergent trends from the data, which suggest the predominance of monologic pedagogies at MTC. In the third section we explore conceptions of 'critical thinking' and debate the importance of 'critical thinking' dispositions to initial teacher development programs. Our view is that pedagogies at MTC are incapable of developing teachers that are immersed in the Socratic tradition of critical self-examination and critical dialogue. In the final section we provide concluding remarks.

\section{Methodology}

\section{Focused group interviews}

The data on which this article draws was gathered through focused group interviews conducted with final [third] year students at MTC. Our choice of focused group interviews was informed by the theoretical frameworks of hermeneutics, phenomenology and critical theory. As Martin Eger (1993a) argues, in educational practice a hermeneutic approach has to be advocated not just to oppose 'de-contextualization', but mainly to foster 'critical thinking'. He contends that by questioning the putative neutrality of reading a text, hermeneutics supports constructivist theories of knowledge and communication. By criticising over-dependence on formal methods, it highlights the linguistic component of the sciences their shared, social elements. And by emphasizing history, tradition, cultural perspectives, and by placing meaning at the centre of inquiry, hermeneutics aims to shore up in all scholarly activity an apparently declining human dimension (Eger 1993a, 1). In a sequel to the above-cited publication Eger (1993b, 304) notes that as self-conscious interpretation hermeneutics becomes relevant in that "for each of the viewpoints selected, in each specific context, an interpretation of the object within that context is called for". We argue that hermeneutics fosters philosophical dialogue as depicted in Plato's dialogues such as The Republic, Meno, Protagoras, and Euthyphro. For Gonzales $(2006,313)$, hermeneutics is "fundamentally and inescapably dialectical". We understand dialectic to mean "the practice and theory of conversations" (Krabbe 2000, 205). As Krabbe $(2000,208)$ elaborates, "The primary purpose of most dialectic practices is not to convince or to persuade, but to attain at a truth of some sort by inquiry".

Regarding phenomenology, De Vos et al $(2003,273)$ argue that "phenomenology aims to understand and interpret the meaning that subjects give to their everyday lives". Our view is that the interpretive and reflective aspects of focused group interviews lend themselves to phenomenology and critical theory. Reflection is embedded in phenomenology given that phenomenology is a philosophy that concerns itself with human experience as a mixture of feeling, awareness and

1 See Eamonn Callan. (1997). Creating Citizens: Political Education and Liberal Democracy. Oxford: Clarendon Press. 
consciousness (Higgs and Smith 2002). From its roots at the Frankfurt School 'critical thinking' has always been portrayed as "a reflective theory which gives agents a kind of knowledge inherently productive of enlightenment and emancipation" (Geuss 1981, 2). In its Habermasian sense 'critical theory' turns out to be 'hermeneutically-informed' (Nuyen 1995, 431). Its "method of procedure is immanent criticism. Immanent criticism confronts existence in its historical context, with the claims of its conceptual principles, in order to criticise the relation between the two and thus transcend them" (Held 1989, 183). However, Held $(1990,14)$ cautions that 'critical theory' "does not form a unity. It does not mean the same thing to all its adherents". He differentiates between, on the one hand the work of Max Horkheimer, Theodor Adorno, Herbert Marcuse, Leo Lewenthal, and Frederick Pollock, for whom he reserves the term 'the Frankfurt school'. And on the other hand Jürgen Habermas, "whose recent work in philosophy and sociology recasts the notion of critical theory" (Held 1990, 15).

\section{The participants}

The study's participants comprised all the twenty (20) third year students at MTC for the 2011 academic year. 16 of these had O-Level while only 4 had A-Level. 18 were females and only 2 were males, which confirms the established demographic pattern of females outnumbering males in learning programmes. Regard marital status 15 were married while 5 were never married. With regard to academic qualifications of partners 11 were married to graduates while 4 were married to non-graduates. This is an important statistical variable that will highlight a trend in men's feelings of insecurity with marrying an educated woman who engages in critical and/or thought-provoking discussions. In terms of residential area 12 came from rural areas while 8 came from urban areas. The predominance of the rural background of the participants is an important indicator with regard to the influence of gerontocracy on critical thinking dispositions. Regarding political participation 16 participants expressed total apathy while 4 reported they were in a transitional role. This can be attributed to the closed political environment in which the college exists. We will say more on this issue in the discussion section.

\section{The interviews}

Three groups of between six and seven students per group were interviewed. The interview process lasted between 45 minutes to one hour. The interview tool was framed around five question categories as suggested by Hoberg (2001, 140). First, the opening questions, which sought to establish shared characteristics of group members; second, the introductory questions, which aimed at fostering conversation and interaction among group members; third, the transition questions, which aimed at linking the introductory questions with the key questions; fourth, the key questions, which aimed to probe factors that researchers suspected contributed to stifling the development of critical thinking dispositions, and finally, the closing questions, which aimed to wind up the discussions.

To try and establish some kind of group rapport the participants were asked to comment on their perceptions of philosophy of education, and their performance in philosophy of education assignments, and they performed poorly, to reflect on what might be attributed to their poor performance. In the second stage the participants were asked to comment on the presentation of lectures in philosophy of education and how it might have impacted on their attitudes towards the course. Given that the principal object of philosophy of education is the disciplined analysis, criticism and construction of arguments, the participants were asked whether education should be a means for preparing individuals to play a critical role in social and political change. The other issues about which the participants were asked to express their views were the influence of religion; the general conditions in the college and the extent to which they might be attributed to the stifling of critical thinking dispositions; the influence of monologic pedagogy; absence of opportunities for experiential [research and seminars] time on critical thinking dispositions; the influence of gerontocratic orientations; the influence of a politically closed system, and the influence of femininity orientations.

\section{Data management}

The interviews were audio-taped, transcribed, and described using the participants' verbatim responses. Qualitative researchers recognise that "in order to document transparency and for analysis and review of data, all interviews should be recorded and transcribed" (Brod., Tesler., and Christensen 2009). Kidd and Parshall $(2000,298)$ contend that "audiotape is often easier for a transcriptionist to work with than videotape". Importantly though, audio-taping helps researchers "remedy common, everyday memory problem" (Vemuri., Schmandt., Bender., Tellex., and Lassey 2004). 
Vemuri et al $(2004,401)$ argue that while retrieving any information that triggers the memory of the event is sufficient, finding the exact information is necessary, which is why audio-taping is so important to qualitative research.

\section{Ethical considerations}

The study was conducted under the auspices of UNISA's Research Directorate. As such the research processes had to comply with the university's code of research ethics as outlined in UNISA Policy on Research Ethics (2007). The policy states that "participants are autonomous agents who have a right to choose whether or not to be part of the research". Moreover, "researchers should not infringe the autonomy of participants by resorting to coercion, undue influence or the promise of unrealistic benefits" (UNISA 2007, 11). The policy states that "autonomy requires that individuals' participation should be freely given, specific and based on informed consent" (UNISA 2007, 10). As a result the researchers sought the participants' informed consent. An informed consent form explaining the above policy requirements was read out to the participants before the interviews started. And after ensuring they fully understood what they were consenting to, the participants were asked to sign the voluntary consent form. Most important to the dignity of the participants, the policy states that "measures to ensure privacy, anonymity and confidentiality of participants, as well as any risk of breach of confidentiality and anonymity should be explained. If data and identity provided by participants in group discussions cannot be kept anonymous and confidential, this should also be disclosed" (UNISA 2007, 13). Considering that by their very nature focus group interviews cannot guarantee confidentiality and non-disclosure of information the participants were asked to consider the informed consent form as proxy of non-disclosure agreement that binds them not to disclosure any information about the interviews. The researchers made a commitment not to disclose the identities of the participants during compilation of the report and dissemination of the findings, and instead to use non-traceable pseudonyms such as 'participant 1', 'participant 2' or 'participants'.

\section{Emergent trends from the data}

The interview transcripts were analysed to identify emergent trends. The identified trends were captured in sentences and/or phrases. The sentences and/or phrases contained verbatim responses that were then categorised. Each category was allocated a descriptive statement which was further divided into subthemes. We now briefly comment on each category and highlight the responses articulated by the participants.

\section{A. On perceptions of the influence of religion on critical thinking dispositions}

The prevailing mood among the participants was that there was an element of coercion at MTC for students to conform to certain religious doctrines, and that deviation from the norm could have serious consequences. One participant made the following remark:

"Try critical discussion on religious issues here at Morgenster College and you'll get deferred".

Our view is that the above response resonates with the views of theorists such as French philosopher Michel Foucault, who argues that modern institutions like big church denominations tend to force their adherents to conform to certain sets of rules (Higgs and Smith 2000). Higgs and Smith $(2002,12)$ argue that educators cannot teach students to be critical while at the same time encouraging them to conform to a set of fixed and inflexible rules. This is because conformity to fixed and inflexible rules is tantamount to indoctrination (Garrison 1986; Macmillan 1983; Snook 1972a, 1972b, 1970). Snook $(1970,70)$ argues that "the essence of indoctrination lies in the method. Its evil lies in the intention". He goes further to argue that "to the degree that the learner becomes unfit to consider the matter on its merit, indoctrination has occurred. To the extent that a person takes steps to bring this about, indoctrination is morally wrong". For Griessel and Oberholzer $(1994,19)$, "indoctrination binds the child and degrades him to just one of a mass of people who may not think for himself", and "goes hand in hand with intolerance of critical questions".

\section{B. On negative self concept with respect to critical thinking dispositions}

The students' responses to this category suggested evidence of negative self-concept with regard to the capacity for critical thinking. Some students expressed doubts about their own capacity to give authoritative opinions on, or be critical 
of the views of renowned African leaders. For instance, one participant stated her views as follows:

The other stated:

"When I size myself against Nyerere, I am nothing intellectually to critique his ideas".

And

"I am not yet intellectually mature to hold some philosophical debates".

"I don't think I will ever become a philosopher - I don't have the intelligence". "Look at us, just 'O' Level school leavers".

There was also evidence that the students at the college regarded some views or opinions as having fixed meanings and therefore not to be tempered with, which is reminiscent of a positivist attitude of the fixed and predictable nature of [objective] scientific knowledge. For instance, one participant stated that

"Some issues are by nature good we shouldn't waste time critiquing them".

\section{On the influence of monologic pedagogy and its implications for the development of critical thinking dispositions}

In the introduction we alluded to the culture of monologic pedagogy at MTC - a pedagogical practice in which knowledge is treated as fixed bodies of facts and theories that are to be transferred to the learners, who are deemed external to the so-called knowledge. Monologic pedagogy tends to treat students as tabula rasa - 'clean slates', 'empty vessels' or 'receptacles' that need to be filled with 'facts' 'formulae', and 'theorems', which are presumed to constitute 'worthwhile knowledge' (Gravett 2001). This was confirmed by the following response from one participant:

"Presentations in lecture rooms are about the lecturers' knowledge - you have to consume the knowledge".

As we mentioned above Paulo Freire has written extensively on this type of pedagogical approach which he labelled the 'banking concept of education'. Freire $(1996,53)$ argues that in the 'banking concept' education becomes "an act of depositing, in which the students are depositories and the teacher is the depositor. Instead of communicating, the teacher issues communiqués and makes deposits which the students patiently receive, memorise, and repeat". He further argues that "it follows logically from the banking notion of consciousness that the educator's role is to regulate the way the world 'enters into' the student. The teacher's task is to organise a process which already occurs spontaneously, to 'fill' the students by making deposits of information which he or she considers to be true knowledge" (Freire 1996, 57). Consistent with the above sketching of the banking concept of education some participants informed the interviewing team that

"Some lecturers just come and read notes to us".

"Sometimes you feel that you should reproduce what the 'fundis' give to you".

Letseka $(1995,295)$ cautions though that the "so-called learning where the flow of information is one-dimensional, that is, where one element or subsystem plays a major or dominant role in the operation of the system as a whole, cannot, logically speaking, be called education. Within philosophy of education discourse such an 'interaction' qualifies as indoctrination".

\section{On the absence of opportunities for experiential time on critical thinking dispositions}

Freire (1996) argues that the essence of education is the practice of freedom, dialogics and dialogue, which are the awakening of critical consciousness through the investigation of generative themes. For Freire $(1996,73)$, "true dialogue cannot exist unless the dialoguers engage in critical thinking - thinking which discerns an indivisible solidarity between the world and the people and admits of no dichotomy between them - thinking which perceives reality as process, as transformation, rather than as a static entity - thinking which does not separate itself from action, but constantly immerses itself in temporality without fear of the risks involved". It was evident from the participants' responses that at MTC there was absence of Freire's "awakening of critical consciousness through the investigation of generative themes". As one participant lamented:

"Our timetable is packed more than the primary school timetable".

Other participants informed the interviewing team:

"We hand in assignments when they are still hot [we work on the assignments in the night when the due date for submission is the next day]". 
"There is no time to digest what you are told".

"We have no time to think about the notes given to us".

"In other areas we reproduce the notes due to lack of time".

This last remark confirms the prevalence of the 'banking concept' at MTC. The phrase 'reproduces the notes' underscores regurgitation of memorised information. But is memorising information the same as studying for the purpose of learning? We don't think so. Freire $(2005,40)$ is unequivocal that "to study is to uncover; it is to gain a more exact comprehension of an object; it is to realise its relationship to other objects". Thus teaching cannot be a "mechanical transference from which results machinelike memorization". For Freire, "critical study correlates with teaching that is equally critical, which necessarily demands a critical way of comprehending and of realising the reading of the word and that of the world, the reading of text and of context".

\section{E. On the influence of a closed political system on the development of critical thinking dispositions}

Our starting point in the study was that the college was a closed system like the political environment in which it exists. Letseka's $(1995,289)$ contends that "closed systems would be those that cannot import energy". In social theory and political practice dictatorial, military, totalitarian, autocratic, tyrannical and other single-handed forms of government are conspicuous examples of closed systems. Our view is that educational practice should be marked by open discussion instead of top-down flow of instructions and communiqués. Thus the following response flies in the face of Freire's (2005) view that "the essence of education is the practice of freedom, dialogics and dialogue":

\section{"Follow what you are told and have peace - be critical and philosophical and get into pieces".}

Another participant echoed a view typical of someone living in a politically censored environment, and who has, in the process resigned to self-censoring herself:

\section{"About issues concerning politics, I am not prepared to comment".}

When probed further about their reluctance to get involved in political issues some participants made the following comments:

"I am afraid you may not finish the course".

"Why would one dice with trouble".

An environment in which students are regarded as 'empty vessels' or 'receptacles' is antithetical to 'critical thinking'. Letseka $(1995,295)$ argues that "education involves learning, and learning presupposes the acquisition of knowledge. But knowledge is not a thing 'out there', possessed by some idealised specialist or expert". To that end "an education situation ought to be characterised by a dual flow of information where the learner openly expresses his/her curiosity through questions and queries, and the teacher directs these questions and queries by re-posing the question to enable the learner to see his/her problems in a different light and therefore reflect on them from a more informed position" (Letseka 1995, 295-96). This requires "a shift from viewing education as a system in which one teacher provides information to many students, towards a system in which there are many information resources available for one student, only one of which is the teacher" (Letseka 1995, 296).

\section{F. On the influence of gerontocracy on critical thinking dispositions.}

The Oxford English Dictionary defines gerontocracy as "government by a council of elders"/"a governing body consisting of old people"/ "a state or government in which old people rule". We are not presuming here that there is anything wrong with gerontocracy. As Canadian philosopher of education Kieran Egan $(1992,641)$ argues, in oral cultures elders are of such considerable socio-political and cultural importance. They are deemed "qualified to speak authoritatively on public matters and to mediate on socio-political and cultural issues because they articulate the meaning of life". Yale University political scientist Robert Alan Dahl $(1998,10)$ notes that tribal elders "see themselves as about equal in being well 
qualified to have a say in governing the group". David M. Ryfe $(2005,63)$, professor of Journalism at Middle Tennessee State University, USA insists that the elder "anchor reality by organising experience and instilling a normative commitment to civic identities and values". While Nelson Mandela $(1995,24)$ posits that the elders are "wise men who retained the knowledge of tribal history and custom in their heads and whose opinions carried great weight". A contested issue here is that invariably the term 'elders' refers to males, which suggests that oral cultures are patriarchal. American feminist political philosopher Susan Moller Okin (1999) argued that most of the world's traditions and cultures "are quite distinctly patriarchal".

When the participants were probed on the possible influence of gerontocracy on the development of critical thinking dispositions some of them responded as follows:

"Whatever elders say is indisputable".

This smacked of total submission to the finality of elders' views and opinions. One participant expressed frustration on the elders' monopoly of knowledge:

"You get current information on the internet but you are told that experience counts most".

'Old people say, 'Takabva nako kumhunga hakuna ipwa' [I have experienced a lot in this area so get it from me']. In sheer resignation to the elders' monopoly on knowledge one participant remarked as follows:

"Keep quiet, old people do not make mistakes".

"Philosophise with age-mates, but not among the elders".

Fear of sanction for being critical loomed large among some of participants. For instance, the following comment underscored gerontocratic power (Likes 2005; Burbules 1986; Foucault 1980):

"Even when elders make glaring mistakes, keep it to yourself or else ...."

"One risks ostracism when one tries to philosophise on some issues with elders".

Desperation to pass meant students subservience over human agency, as the following remarks attest:

"If you want to pass be on the side of the lecturer".

"Lecturers psychologically quarantine you when you try to show philosophical prowess".

\section{G. On the Influence of femininity orientations on critical thinking dispositions.}

Female participants shared experiences of socialisation by elderly women into 'socially desirable' gendered roles and expectations, which reinforced the patriarchal nature to which Okin (1999) referred above. For instance:

"At 'kitchen parties' older women advise us not to be critical in the home".

"When one gets married, one's aunts advise her not to be argumentative in the home".

"In my religious group, women play subservient roles - they are not even allowed to preach".

It is evident that critical dialogue which we identified in the work of Freire $(2005,1996)$, and critical self-examination reminiscent in the dialogues of Plato about which we briefly comment below do not have a place at MTC.

"A good woman is one who obeys".

"Critiquing societal issues requires a very strong and courageous woman especially if one is young".

It emerged that even the 'family' - in-laws and the husband, do not expect a woman to be vocal or assertive. A female participant was clear that it was deemed offensive for a woman to engage in critical discourse with her in-laws:

"In-laws do not like critical women".

There was tacit understanding among the women participants that they would not risk relationships with their husbands or their marriages by asking critical questions or engaging in critical discussions:

"Your critiquing should end at college, not in the home".

"Try it in the home and you are finished".

There was evidence of a paradox with respect to the importance of a tertiary qualification to a family and the consternation such a qualification caused on husbands:

"Your husband would think you are big headed because you have been to college".

Indeed a male participant confirmed this consternation with regard to marrying and living with an educated woman who engages in critical debates:

"I would not like to marry a woman who would engage me in debates".

In the final section below we briefly sketch conceptions of critical thinking and flesh out the reasons why critical thinking is so important to teaching and learning. 


\section{But what is 'critical thinking' and why is it so important?}

\section{On conceptions of critical thinking}

The notion of 'critical thinking' has surfaced at various levels of this article. For instance, Paulo Freire (1996) suggested that true dialogue cannot exist unless the dialoguers engage in critical thinking; Martin Eger (1993a) proposed that in educational practice a hermeneutic approach should foster 'critical thinking'. And Anh Tuan Nuyen (1995) argued that 'critical theory', on which 'critical thinking' is anchored, is a 'hermeneutically-informed' discipline. In this final section we briefly sketch the underlying assumptions on the notion of 'critical thinking' and comment on why it is so important for educational theory and practice. Our aim is to highlight the potential dangers of initial teacher development programs, such as those at MTC, which preclude the development of 'critical thinking' dispositions. The words 'criticise' and 'critical' derive their meanings from Latin or Greek words: criticus and kritikos, whose meanings approximate 'able to make judgments'.

We take Socrates to symbolise a critical thinker and master perfectionist of the art of critical questioning. As prominent intellectual at Princeton University, USA, Cornel West $(2004,16)$ observes, the Socratic commitment to questioning requires a relentless self-examination and critique of authority, motivated by an endless quest for intellectual integrity and moral consistency. It manifests in fearless speech - parrhesia - that unsettles, unnerves, and unhouses people from their uncritical sleepwalking. West $(2004,208-209)$ describes Socrates as an exemplary democratic citizen whose love for wisdom held not only that the unexamined life is not worth living, but also that to be human and a democratic citizen requires that one musters the courage to think critically for oneself. Socratic questioning wrestles with basic questions such as: 'what is justice?', 'what is courage?', 'what is piety?', 'what is love?', and yields intellectual integrity, philosophic humility, and personal sincerity. It is our submission that initial teacher development programs at MTC should be reviewed so that they embrace the kind of Socratic self-examination to which Cornel West refers above.

Among the five American theorists mentioned above who have written extensively on 'critical thinking' we are more at home with the work of Robert Ennis, of the University of Illinois, Chicago, USA. The reason for this is that Ennis relates 'critical thinking' to education and grapples with ways it can result in 'critical thinking' dispositions among learners. Ennis $(1989,4)$ defines critical thinking as "reasonable reflective thinking focused on deciding what to believe or do". Reflection "is an important human activity in which people recapture their experience, think about it, mull it over and evaluate it" (Boud, Keogh and Walker 1996, 33). Reflection is embedded in phenomenology - a philosophy that concerns itself with human experience as a mixture of feeling, awareness and consciousness that can be understood by looking again and 'reflecting' on the experience (Higgs and Smith 2002). But 'reflection' also has its roots in hermeneutics, which is a philosophy that views life as a process of interpretation of experience (Higgs and Smith 2002; Hoberg 2001).

Our concern in this article is with the development of critical thinking dispositions among MTC student. Ennis $(1996,166)$ defines a disposition as "a tendency to do something, given certain conditions". He argues that in reasonably and effectively going about deciding what to believe or do, individuals with 'critical thinking' dispositions will be inclined to do most of the following things: judge the credibility of sources; identify conclusions, reasons and assumptions; judge the quality of an argument, including the acceptability of its reasons, assumptions and evidence; develop and defend a position on an issue; ask appropriate clarifying questions; plan experiments and judge experimental designs; define terms in a way appropriate for the context; be open-minded; try to be well informed, and draw conclusions when warranted, but with caution (Ennis 1993, 180).

Peg Title $(2011,4)$, whose work on 'critical thinking' resonates with Ennis's thoughts writes as follows in his book, Critical Thinking: An Appeal to Reason: "critical thinking is judicious reasoning about what to believe, and therefore, what to do". Title contends that 'critical thinking' is thinking carefully about something in order to evaluate it and ultimately decide whether or not it is something you should accept. In other words, critical thinking' is judgmental. It is "judicious reasoning that is deliberate and thorough". It is a skill. Not something you can just memorise, or look up. As a skill, "it is something you get better at, gradually, and with practice". Being a 'critical thinker' is about becoming a stern critic of your own thinking (Paul and Elder 2002, 7).

On why critical thinking is so important to teaching and learning

But why is 'critical thinking' so important to teaching and learning? Title $(2011,9)$ argues that people who engage in 'critical thinking' are able to provide evidence and reasoning for the opinions they hold. Thus 'critical thinking' is based on rational thought, which is superior to emotion, intuition, or faith as a basis for belief and action (Title 2011, 11). In their book, Asking the Right Questions: a Guide to Critical Thinking, Neil Browne and Stuart Keeley (2007) argue that critical 
thinkers find it satisfying to say 'no' to an idea or opinion and to know why that response is appropriate. They can provide good reasons for their actions because they are autonomous thinkers who think for themselves. They use critical skills and insights to reveal and eradicate beliefs to which they cannot rationally assent (Paul 1990, 12). In formulating new beliefs, critical thinkers do not passively accept the beliefs of others; rather, they analyse issues themselves, reject unjustified authorities, and recognise the contributions of justified authorities. They thoughtfully form principles of thought and action and do not mindlessly accept those presented to them. They do not accept as true, or reject as false, beliefs they do not understand. They are not easily manipulated. Browne and Keeley $(2007,11)$ posit that if you regularly use the panning-for-gold approach, then anything that gets into your head will have been systematically examined first. When an idea or belief does pass the criteria developed here, it will make sense to agree with it - at least until new evidence appears.

We want to close by quoting the editorial of the journal, Humanist in Canada: A Voice of Reason and Community. Our view is that this quotation captures the point we are trying to argue in this article regarding the centrality of 'critical thinking' and 'critical thinking' dispositions to educational theory and practice:

Critical thinking entails (among other things): learning to make intelligent judgments based on evidence; insistence upon a critical evaluation of evidence; understanding of what constitutes good evidence; refusal to be certain about any knowledge, regardless of evidence; understanding that we live in a world of probabilities rather than certainties; unwillingness to accept or reject an argument because of its source; being respectful of arguments from intelligent, reliable and experienced authority; familiarity with the various techniques of argument; striving for logical consistency; being alert to techniques of deception; understanding probability; being sceptical of all significant claims to truth, and being committed to searching for truth (Bauslaugh 2004, 2).

\section{Conclusion}

In this article we have explored obstacles to the development of critical thinking dispositions among student teachers at Morgenster Teachers' College, in Masvingo, Zimbabwe. We drew on the data from the study's focus group interviews and highlighted among other things, the prevalence of monologic pedagogy at MTC. We argued that given monologic pedagogy's treatment of students as tabula rasa - 'blank slates', 'empty vessels' or 'receptacles' that need to be filled with 'facts', 'formulae', and 'theorems', it is potentially indoctrinatory. It is our contention that monologic pedagogy is analogous to indoctrination and inconsistent with the development of critical thinking dispositions.

We sketched conceptions of 'critical thinking' and 'critical thinking dispositions' and linked them with hermeneutics, phenomenology and critical theory. We argued that Hermeneutics fosters philosophical dialogue reminiscent of Plato's dialogues in The Republic, Meno, Protagoras, and Euthyphro. Phenomenology is a philosophy that concerns itself with human experience as a mixture of feeling, awareness and consciousness. We argued that critical theory is not only 'hermeneutically-informed', but it is also premised on immanent criticism. The latter confronts existence in its historical context. We suggested a shift in Morgenster Teachers' College's pedagogical principles and practices, away from the 'banking concept of education' towards education as the practice of freedom and critical dialogue. As Paolo Freire (1996) argues, true dialogue only exists when the dialoguers engage in critical thinking. That is, thinking which perceives reality as process, as transformation, rather than as a static entity. Critical thinking does not separate itself from action, but constantly immerses itself in temporality without fear of the risks involved.

\section{References}

Bauslaugh, G. (2004). Editorial: Reason over Passion. Humanist in Canada, 37 (3), 2-3.

Beyer, B. K. (1988). Developing a Thinking Skills Program. Boston: Allyn \& Bacon.

Boud, D., Keogh, R., \& Walker, D. (1996). Promoting Reflection in Learning. London: Penguin Books.

Brod, M., Tesler, L. E., \& Christensen, T. L. (2009). Qualitative research and content validity: developing best practices based on science and experience. Quality of Life Research, 18, 263 - 1278.

Browne, M, N., \& Stuart Keeley, S. M. (1997). Asking the Right Questions: A Guide to Critical Thinking. New Jersey: Pearson Education.

Burbules, N. C. (1986). A theory of power in education. Educational Theory, 36 (2), 95-114.

Dahl, R. A. (1998). On Democracy. New Haven and London: Yale University Press.

Marie-France Daniel F., \& Auriac, E. (2011). Philosophy, critical thinking and philosophy for children. Educational Philosophy and Theory, 43 (5), 415-435. 
De Vos, A. S., Strydom, H., Fouche, C.B., \& Delport, C.L.S. (2003). Research at Grassroots: For the Social Sciences and Human Service Professions. Pretoria: Van Schaik.

Egan, K. (1992). The roles of schools: the place of education. Teachers College Record, 93 (4), 641-655.

Egege, S., \& Kutieleh, S. (2004). Critical thinking: teaching foreign notions to foreign students. International Education Journal, 4 (4), $75-$ 85.

Eger, M. (1993a). Hermeneutics as an approach to science: Part I. Science and Education 2:1-29.

Eger, M. (1993a). Hermeneutics as an approach to science: Part II. Science and Education, 2, 303-328.

Ennis, R. H. (1996). Critical thinking dispositions: their nature and assessability. Informal Logic 18 (2 and 3), 165-182.

Ennis, R.H. (1993). Critical thinking assessment. Theory into Practice, 32 (3), 179-186.

Ennis, R. H. (1989). Critical thinking and subject specificity: clarification and needed research. Educational Researcher, 18 (3), 4-10.

Freire, P. (2005). Teachers as Cultural Workers: Letter to those who Dare Teach. Boulder, Colorado: Westview Press.

Freire, P. (1996). Pedagogy of the Oppressed. London: Penguin Books.

Foucault, M. (1980) Power/Knowledge: Selected Interviews and Other Writings 1972-1979. New York: Pantheon Books.

Garrison, J. W. (1986). The paradox of indoctrination: a solution. Synthese, 68 (2), 261-273.

Geuss, R. (1981). The Idea of a Critical Theory: Habermas and the Frankfurt School. Cambridge: Cambridge University Press.

Gonzales, F. J. (2006). Dialectic and dialogue in the hermeneutics of Paul Ricoeur and H. G. Gadamer. Continental Philosophy Review, $39,313-354$.

Griessel, G.A.J., \& Orberholzer, M.O. (1994). Philosophy of Education: A Study Manual for Beginners. Via Afrika: Pretoria.

Held, D. (1990). Introduction to Critical Theory: Horkheimer and Habermas. Cambridge, UK: Polity Press.

Higgs, P., \& Smith, J. (2000). Rethinking our World. Cape Town: Juta.

Hoberg, S.M. (2001). Research methodology: Education Management Study Guide 2, MEDEM 2-R. Pretoria: UNISA Press.

Kidd, P.S., \& Parshall, M.B. (2000). Getting the focus group: enhancing analytical rigor in focus group research. Qualitative Health Research, 10 (3), 293-308.

Krabbe, E. C. W. (2000). Meeting in the house of Callias: rhetoric and dialectic. Argumentation, 14, 205-217.

Letseka, M. (1995). Systems theory and educational discourse. In Philip Higgs (ed) Metatheories in Philosophy of Education. Johannesburg: Heinemann.

Lipman, M. (1995). Good Thinking. Inquiry: Critical Thinking across Disciplines, 15, 37-41.

Lipman, M. (1988). Critical Thinking - What Can It Be? Educational Leadership, 46 (1), 38 - 43.

Lukes, S. (2005) Power: A Radical View. London: Macmillan.

Macmillan, C. J. B. (1983). On certainty and indoctrination. Synthese, 56 (3), 363-372.

Mandela, N (1995) Long Walk to Freedom: The Autobiography of Nelson Mandela. London: Abacus.

McPeck, J. (1994). Critical Thinking and the 'Trivial Pursuit' Theory of Knowledge. In Kerry, S. Walters (ed) Re-Thinking Reason. New Perspectives in Critical Thinking. New York: State University of New York Press.

McPeck, J. (1991). What is Learned In Informal Logic? Teaching Philosophy, 14, 25-34.

uyen, A. T. (1995). Critique of ideology: hermeneutics or critical theory. Human Studies, 17, 419- 432.

Okin, S. M. (ed) (1999). Is Multiculturalism Bad for Women? Princeton University Press: New Jersey.

Paul, R. W., \& Elder, L. (2002). Critical Thinking: Tools for Taking Charge of your Professional and Personal Life. New Jersey: Pearson Education.

Paul, R. W. (1990). Critical Thinking: What Every Person Needs to Survive in a Rapidly Changing World. Santa Rosa, CA: Foundation for Critical Thinking.

Ryfe, D. M. (2005). Does deliberative democracy work? Annual Review of Political Science, 8, 49-71.

Siegel, H. (1988). Educating Reason: Rationality, Critical Thinking and Education. New York: Routledge.

Siegel, H. (2003). Cultivating Reason. In Randal Curren (ed.) A Companion to the Philosophy of Education. Oxford: Blackwell.

Schlosser, C., Visser, L. V., \& Visser, L. (2003). Critical thinking in distance education and traditional education. The Quarterly Review of Distance Education, 4 (4), 401-407.

Snook, I. A. (1972a). Indoctrination and Education. London: Routledge \& Kegan Paul.

Snook, I. A. (ed) (1972b). Concepts of Indoctrination: Philosophical Papers. London: Routledge \& Kegan Paul.

Snook, I. A. (1970). The concept of indoctrination. Studies on Philosophy and Education, 7(2), 65-108.

Title, P. (2011). Critical Thinking: An Appeal to Reason. New York: Routledge.

UNISA. (2007). Policy on Research Ethics. Pretoria: UNISA Press.

Van den Berg, M. E. S. (2000). Is there a need for critical thinking skills' modules at tertiary level? South African Journal of Higher Education, 1(14), 96-107.

Vemuri, S., Schmandt, C., Bender, W., Tellex, S., \& Lassey, B. 2004. An Audio-Based Personal Memory Aid. In Nigel Davis., Elizabeth D. Mynatt., \& Itiro Siio (eds) UbiComp 2004: Ubiquitous Computing: 6 $6^{\text {th }}$ International Conference, Nottingham, UK, September 2004 Proceedings. Berlin: Springer-Verlag.

West, C. (2004). Democracy Matters: Winning the Fight against Imperialism. New York: Penguin Press. 